\title{
PENGARUH PENDAPATAN BUNGA TERHADAP PROFITABILITAS PADA PT. BANK JABAR BANTEN
}

\author{
Heni Mulyani \\ Virna Anjarsari \\ henimulyani@upi.edu
}

\begin{abstract}
ABSTRAK
Penelitian ini mengkaji fenomena kinerja profitabilitas (ROA) pada PT. Bank Jabar Banten. Salah satu faktor yang mempengaruhi profitabilitas adalah pendapatan bunga. Pendapatan bunga merupakan pendapatan terbesar yang diterima bank dari kegiatan operasionalnya. Penelitian ini bertujuan untuk mengetahui pengaruh pendapatan bunga terhadap profitabilitas pada PT. Bank Jabar Banten. Penelitian ini menggunakan metode deskriptif verifikatif. Sumber data yang digunakan berupa data laporan keuangan publikasi triwulan PT. Bank Jabar Banten periode Maret 2003 sampai dengan Desember 2010 yaitu neraca dan laporan laba/rugi yang merupakan data sekunder. Untuk menganalisis data penelitian, digunakan regresi linier sederhana. Berdasarkan hasil analisis regresi linier sederhana diperoleh persamaan $\hat{Y}=0,91+1,10 X$, dari persamaan tersebut dapat disimpulkan bahwa pendapatan bunga mempunyai pengaruh positif terhadap profitabilitas, dimana setiap kenaikan pendapatan bunga akan mengakibatkan kenaikan profitabilitas (ROA) sebesar 1,10 kali, sebaliknya apabila terjadi penurunan pendapatan bunga maka akan mengakibatkan penurunan profitabilitas (ROA) sebesar 1,10 kali.
\end{abstract}

Kata Kunci: Pendapatan bunga, profitabilitas bank

\section{Pendahuluan}

\begin{tabular}{lrr}
\multicolumn{2}{c}{ Pemberian kredit dan } \\
$\begin{array}{l}\text { penerimaan simpanan nasabah } \\
\text { merupakan }\end{array}$
\end{tabular} operasional bank. Kegiatan yang dilakukan bank tersebut tidak lepas dari tujuan fundamental bank yaitu mencari keuntungan atau laba. Kegiatan menanamkan dana dalam aktiva produktif dan pemberian jasa perbankan merupakan kegiatan bank dalam rangka usaha memperoleh pendapatan. Bank harus dapat mengelola penyaluran dana dan penempatan dana tersebut secara optimal. Semakin baik pengelolaan kegiatan tersebut maka akan semakin besar pula pendapatan yang diperoleh bank. Pendapatan yang diperoleh bank tersebut dikelompokan menjadi dua kelompok utama, yaitu pendapatan bunga dan pendapatan non bunga.

PT. Bank Jabar Banten sebagai salah satu bank BUMD milik pemerintah Provinsi Jawa Barat dan Banten melaksanakan kegiatan usaha yakni menyalurkan kredit untuk keperluan investasi dan modal kerja dalam pelaksanaan aktivitasnya. Selain itu, PT. Bank Jabar Banten dituntut untuk memberikan pelayanan yang baik dan memuaskan. Hal ini disebabkan 
karena nasabah mendambakan bank yang benar-benar dapat berperan sebagai sahabat dan penasehat yang dapat memberikan pelayanan secara tepat.

Dalam menjalankan peranan bagi masyarakat, bank dituntut untuk dapat meningkatkan kinerja perusahaan atau melakukan perkembangan-perkembangan seiring dengan perubahan ekonomi, perubahan kondisi nasabah, maupun kebutuhan bank itu sendiri serta harus dapat mengambil keputusan yang tepat dalam mengevaluasi dan merencanakan aktivitas perusahaan. Dalam pelaksanaannya, bank perlu mengetahui kondisi keuangan yang merupakan gambaran tingkat kesehatan bank dengan menggunakan analisis kinerja keuangan bank. Salah satu indikator kesehatan bank adalah dinilai dari segi profitabilitas yang menggambarkan kemampuan perusahaan untuk mendapatkan laba. Profitabilitas merupakan cermin efektivitas dan efesiensi pelaksanaan operasional bank. Bank yang sehat selain harus mempunyai modal yang cukup, memelihara likuiditas, dan menjaga kualitas asetnya dengan baik, bank juga harus mampu menghasilkan profit yang layak. Perolehan profit yang layak sangat diperlukan setiap bank untuk meningkatkan minat para pemilik dana dalam menitipkan uang mereka di bank tersebut, guna mendanai perluasan usaha serta membiayai usaha peningkatan mutu jasa. Bank perlu mengendalikan profitabilitas agar tetap berada pada posisi yang ideal bagi perusahaan agar dapat mempertahankan kelangsungan usahanya.

Perolehan profitabilitas suatu bank dapat dinilai dari beberapa aspek, salah satunya dapat dilihat dari besar Return On Assets (ROA) yang dicapainya. Perolehan profitabilitas PT. Bank Jabar Banten berdasarkan ROA dari tahun ke tahun mengalami fluktuasi, kadang naik kadang turun.

Perkembangan profit yang diukur dengan Return on Assets (ROA) pada PT. Bank Jabar Banten selama tujuh tahun mengalami fluktuasi dimana tahun 2005, 2008 dan 2009 mengalami penurunan yang dirasakan bank belum optimal melakukan usahanya sehingga profitabilitas bank menurun tapi sudah berada pada nilai yang bagus karena rata-rata diatas 1,5\% seperti yang telah ditetapkan oleh BI sebesar $1,5 \%$.

Pendapatan bank adalah pendapatan yang berasal dari transaksi pinjaman dan penempatan dana pada bank lain, serta penanaman dana lainnya baik dalam bentuk surat berharga di pasar uang ataupun penanaman dalam bentuk penyertaan. Oleh sebab itu sampai saat ini sebagian besar bank masih memfokuskan kegiatan penanaman dananya dalam bentuk aktiva produktif terutama penyaluran kredit, sehingga pendapatan operasional bank salah satu sumbernya berasal dari pendapatan bunga. Dengan demikian pendapatan bunga masih mendominasi sumber pendapatan bank. Dahlan Siamat (2001:94) mengatakan bahwa " Bank memperoleh pendapatan dari bunga kredit atau surat-surat berharga yang akan meningkatkan perolehan laba bank".

Salah satu penyebab turunnya profitabilitas adalah adanya kredit masalah yaitu ketidakmampuan nasabah dalam menyelesaikan kewajiban-kewajiban bank dalam bentuk pembayaran kembali pokoknya dan atau 
pembayaran bunga, maka pendapatan bank tersebut menjadi turun karena nasabah tidak mampu membayar kreditnya. Bank harus dapat mengelola penyaluran dana dan penempatan dana tersebut secara optimal. Semakin baik pengelolaan kegiatan tersebut maka akan semakin besar pula pendapatan yang diperoleh bank. Tingginya pendapatan bunga yang diperoleh bank akan berpeluang meningkatkan perolehan laba dan secara tidak langsung akan ikut meningkatkan besarnya profitabilitas. Sebaliknya jika pendapatan kecil, maka laba bersih yang diperoleh bank akan berpeluang menjadi kecil atau menurun dan profitabilitas pun akan menurun. Karena pendapatan bunga yang diperoleh dapat mempengaruhi profitabilitas bank maka bank harus dapat mengelola kegiatan yang dapat menghasilkan pendapatan bunga tersebut dengan baik.

Adapun masalah dalam penelitian ini dapat dirumuskan sebagai berikut:

a. Bagaimana deskripsi pendapatan bunga pada PT. Bank Jabar Banten

b. Bagaimana deskripsi profitabilitas pada PT. Bank Jabar Banten

c. Bagaimana pengaruh pendapatan bunga terhadap profitabilitas pada PT. Bank Jabar Banten

\section{Landasan Teori}

Pendapatan bank merupakan penghasilan yang diperoleh bank baik dari kegiatan utama operasional maupun non utama operasionalnya. Bank memperoleh pendapatan bunga dari penanaman dana di bank Indonesia, penempatan pada bank lain, serta penanaman dana pada pihak ketiga bukan bank baik dalam bentuk rupiah maupun valuta asing. Pendapatan bunga dari penanaman dana pada Bank Indonesia antara lain giro, Sertifikat Bank Indonesia (SBI), call money, dan sebagainya. Pendapatan bunga dari penanaman dana pada bank lain diantaranya giro, interbank call money, simpanan berjangka, surat berharga, kredit yang diberikan, tabungan dan sebagainya. Sedangkan pendapatan bunga dari pihak ketiga bukan bank antara lain kredit yang diberikan, surat berharga, dan sebagainya.

Provisi dan komisi kredit merupakan pendapatan dari administrasi yang berkaitan langsung dengan kegiatan pemberian kredit oleh bank baik dalam bentuk rupiah maupun valuta asing. Pendapatan bunga dari aktiva produktif oleh bank diakui sebagai pendapatan bank secara akural (accrual basis) atau diakui bank sebagai pendapatan pada saat jatuh waktu bunga dan bukan pada saat uang diterima kecuali pendapatan bunga dari aktiva produktif non performing.

Besar kecilnya pendapatan bunga yang diperoleh bank dipengaruhi oleh optimalisasi dari penyaluran atau penanaman dana bank, tingkat suku bunga, serta kolektibilitas dari kredit yang disalurkan. Semakin banyak dana yang disalurkan, maka semakin tinggi pendapatan bunga yang diperoleh. Demikian pula jika tingkat kolektibilitas kredit baik maka semakin baik pula pendapatan bunga yang diperoleh bank.

Hingga kini, bank-bank masih terfokus pada kegiatan penanaman dana dalam aktiva produktif terutama kredit. Hal ini menjadikan pendapatan bunga masih menjadi jenis pendapatan yang mendominasi 
pendapatan bank. Tingginya pendapatan bunga akan berpeluang besar meningkatkan laba bank. Laba digunakan sebagai indikator untuk menilai baik tidaknya kinerja atau kemampuan suatu perusahaan. Laba merupakan hasil operasi yang diperoleh perusahaan pada suatu periode yang diukur dengan membandingkan pendapatan yang diperoleh dengan biaya yang dikeluarkan untuk memperoleh keuntungan.

Profit atau laba merupakan indikasi kesuksesan suatu badan usaha dengan mengukur efektivitas dan efesiensi, walaupun tidak semua perusahaan menjadikan Profit sebagai tujuan utamanya tetapi dalam mempertahankan usahanya memerlukan laba. Salah satu sasaran penting bagi organisasi yang berorientasi pada profit adalah menghasilkan laba. Oleh karena itu jumlah laba yang dihasilkan dapat dipakai sebagai salah satu alat ukur efektivitas, karena laba adalah selisih antara pendapatan (yang merupakan ukuran keluaran) dan pengeluaran (yang merupakan ukuran masukan). Laba merupakan keuntungan yang diterima perusahaan, karena perusahaan telah melakukan pengorbanan untuk kepentingan pihak lain.

Menurut Henry Simamora (2000:25) "Laba bersih adalah perbedaan antara pendapatan dengan beban, jikalau pendapatan melebihi beban maka hasilnya laba bersih". Besar kecilnya pendapatan atau laba yang diperoleh perusahaan tergantung pada bunga yang diperolesh perusahaan dengan semua beban yang dikeluarkan atau dibayarkan oleh perusahaan. Dari hasil kegiatan yang dilakukan oleh perusahaan yang akan menghasilkan pendapatan bunga bersih. Dan hanya dari pendapatan bunga bersih itu akan memperoleh keuntungan atau laba bersih bagi perusahaan tersebut. Apabila tidak ada pendapatan bunga bersih, maka laba bersih yang diperoleh akan berkurang atau menurun, karena pendapatan bank bukan hanya dari pendapatan bunga bersih saja, tapi dari biaya-biaya jasa lainnya, seperti dari biaya administrasi, provisi, selisih kurs, jasa layanan deposit box, biaya transfer, biaya kliring, dan lain-lain.

Menurut Lukman Dendawijaya (2009:118) "analisis tingkat profitabilitas bank adalah untuk menganalisis atau mengukur tingkat efesiensi usaha dan profitabilitas yang dicari oleh bank yang bersangkutan". Selain itu rasiorasio dalam kategori ini dapat pula digunakan untuk mengukur tingkat kesehatan bank. Dalam menghitung rasio-rasio profitabilitas ini biasanya dicari hubungan timbal balik antara pos yang terdapat pada laporan laba rugi dengan pos-pos pada neraca bank guna memperoleh berbagai indikasi yang bermanfaat dalam mengukur tingkat efesiensi dan profitabilitas bank.

Analisis profitabilitas menurut Lukman Dendawijaya (2009:118) sebagai berikut:

\section{Return on Assets (ROA)}

Rasio ini digunakan untuk mengukur kemampuan manajemen bank dalam memperoleh keuntungan (laba) secara keseluruhan. Semakin besar Return on Assets (ROA) suatu bank semakin besar pula tingkat keuntungan yang dicapai bank tersebut dan semakin baik pula posisi bank tersebut dari segi penggunaan assets. Rasio ini dirumuskan: 
$R O A$

$=\frac{\text { laba bersih sebelum pajak }}{\text { total aktiva }} \times 100 \%$

(Lukman Dendawijaya, 2009:118)

2. Return on Equity (ROE)

Rasio ini adalah perbandingan antara laba bersih bank dengan Return on Equity (ROE) modal sendiri. Rasio ini dirumuskan sebagai berikut:

$$
\begin{array}{r}
\text { ROE }=\frac{\text { laba bersih }}{\text { modal sendiri }} \times 100 \% \\
\text { (Lukman Dendawijaya, } \\
2009: 119)
\end{array}
$$

Rasio ini banyak diamati oleh para pemegang saham serta para investor di pasar modal yang ingin membeli saham bank yang bersangkutan (jika bank telah go public). Bank Indonesia lebih mementingkan penilaian besarnya Return on Assets (ROA) dan tidak memasukan unsur Return on Equity (ROE). Hal ini dikarenakan bank Indonesia sebagai Pembina dan pengawas perbankan lebih mengutamakan nilai profitabilitas suatu bank.

\section{Rasio Biaya Operasional}

Perbandingan antar biaya operasional dengan pendapatan operasional. Rumusnya sebagai berikut:

Rasio biaya operasional $=\frac{\text { biaya }(\text { beban)operasional }}{\text { pendapatan operasional }} \times 100 \%$

(Lukman Dendawijaya, 2009:119)

Rasio beban operasional digunakan untuk mengukur tingkat efesiensi dan kemampuan bank dalam melakukan kegiatan operasionalnya.

\section{Net Profit Margin (NPM)}

Rasio yang menggambarkan tingkat keuntungan (laba) yang diperoleh bank dibandingkan dengan pendapatan yang diterima dari kegiatan operasionalnya. Rumusnya sebagai berikut:

$$
\begin{array}{r}
N P M \\
\begin{array}{r}
\text { pendapatan operasional } \\
\text { (Lukman Dendawijaya, } \\
2009: 120)
\end{array}
\end{array}
$$

Untuk menilai profitabilitas atau rentabilitas suatu bank, Bank Indonesia mengeluarkan peraturan No.6/10/PBI/2004 tentang Sistem Penilaian Tingkat Kesehatan Bank Umum pasal 4 ayat (4) berisi penilaian terhadap faktor rentabilitas meliputi penilaian terhadap komponen-komponen Return On Assets (ROA), Return On Equity (ROE), Net Interest Margin (NIM), dan tingkat efesiensi bank.

Adapun kriteria minimal
untuk keempat komponen
profitabilitas diatas menurut
Edaran Burat
6/23/DPNP tanggal 31 Mei 2004
adalah:

Tabel 1

Kriteria Minimal Profitabilitas

SE No.6/23/DPNP/2004

\begin{tabular}{|l|c|}
\hline \multicolumn{1}{|c|}{$\begin{array}{c}\text { Komponen } \\
\text { Profitabilitas }\end{array}$} & $\begin{array}{c}\text { Kriteria } \\
\text { Minimal }\end{array}$ \\
\hline $\begin{array}{l}\text { Return On Assets } \\
\text { (ROA) }\end{array}$ & $1,5 \%$ \\
\hline $\begin{array}{l}\text { Return On Equity } \\
\text { (ROE) }\end{array}$ & $12,5 \%$ \\
\hline $\begin{array}{l}\text { Net Profit Margin } \\
\text { (NPM) }\end{array}$ & $2 \%$ \\
\hline $\begin{array}{l}\text { Biaya Operasional } \\
\text { dibandingkan } \\
\text { dengan }\end{array}$ & $\leq 94 \%$ \\
$\begin{array}{l}\text { Pendapatan } \\
\text { Operasional } \\
\text { (BOPO) }\end{array}$ & \\
\hline
\end{tabular}


Dendawijaya (2009:119)

menyatakan bahwa: Dalam penentuan tingkat kesehatan bank, Bank Indonesia lebih mementingkan penilaian besarnya Return on Assets (ROA). Hal ini dikarenakan Bank Indonesia sebagai pembina dan pengawas perbankan lebih mengutamakan nilai profitabilitas suatu bank yang diukur dengan asset yang dananya sebagian besar berasal dari dan simpanan masyarakat.

Berdasarkan hal tersebut, maka rasio profitabilitas dalam penelitian ini yang digunakan yaitu Return on Assets (ROA). Return on Assets (ROA) merupakan rasio profitabilitas yang digunakan untuk mengukur kemampuan bank dalam memperoleh keuntungan (profit), karena rasio ini dipandang lebih baik dari rasio lainnya dalam mengukur efisiensi operasi. Return on Assets (ROA) memberikan gambaran mengenai bagaimana kemampuan perusahaan dalam memanfaatkan total asset yang dimiliki untuk mendatangkan laba.

\section{Metode Penelitian}

Metode yang digunakan peneliti adalah metode deskriptif verifikatif, yaitu suatu metode yang bukan hanya menggambarkan atau mendeskripsikan variabel-variabel yang diteliti, dalam hal ini variabel $X$ yaitu pendapatan bunga dan variabel $Y$ yaitu profitabilitas, tetapi juga menerangkan hubungan, menguji hipotesis, membuat prediksi serta mendapatkan makna dan implikasi dari masalah yang ingin dipecahkan.

Data yang digunakan dalam penelitian ini berupa data sekunder. Data sekunder yang digunakan dalam penelitian ini adalah laporan keuangan publikasi neraca dan laporan laba rugi PT. Bank Jabar Banten periode 2003-2010.

Teknik pengumpulan data merupakan prosedur yang sistematis dan standar untuk memperoleh data yang diperlukan. Data yang digunakan dalam penelitian ini adalah data sekunder yaitu data yang diperoleh melalui dokumen yang dimiliki perusahaan berupa laporan keuangan.

Analisis data yang digunakan yaitu analisis statistik dan analisis profitabilitas. Analisis statistik yaitu untuk menganalisis data sampel dengan skala rasio. Adapun analisis statistik yang digunakan dalam penelitian ini adalah analisis uji linieritas dan analisis regresi linier sederhana. Analisis profitabilitas yaitu untuk menganalisis profitabilitas dengan skala rasio.

\section{dapotesis yang diajukan} penelitian ini adalah "Pendapatan bunga berpengaruh terhadap profitabilitas bank". Pengujian hipotesis dilakukan adalah pengujian hipotesis nol $\left(\mathrm{H}_{0}\right)$ yang menyatakan bahwa koefisien regresi tidak berarti atau tidak signifikan. Sedangkan hipotesis alternatif $\left(\mathrm{H}_{1}\right)$ menyatakan bahwa koefisien regresi berarti signifikan. Jika $\left(\mathrm{H}_{0}\right)$ ditolak maka $\left(\mathrm{H}_{1}\right)$ dapat diterima. Perumusan $\mathrm{H}_{0}$ dan $\mathrm{H}_{1}$ untuk penelitian ini adalah:

$\begin{array}{ll}\mathrm{H}_{0}: \beta=0, & \text { Tidak ada } \\ & \text { pengaruh } \\ & \text { antara } \\ & \text { Pendapatan } \\ & \text { Bunga dengan } \\ & \text { Profitabilitas } \\ & \text { pada PT. Bank } \\ & \text { Jabar Banten. } \\ & \text { Terdapat } \\ \mathrm{H}_{1}: \beta \neq 0, \quad \text { pengaruh }\end{array}$


antara

Pendapatan

Bunga dengan

Profitabilitas

pada PT. Bank

Jabar Banten.

\section{Hasil dan Pembahasan}

Berdasarkan data serta penjelasan yang telah diungkapkan sebelumnya, maka perkembangan pendapatan bunga pada PT. Bank Jabar Banten pada periode akhir tahun 2010 merupakan hasil pendapatan bunga terbesar yang berhasil diperoleh bank selama tujuh tahun terakhir. Sedangkan perolehan jumlah hasil pendapatan bunga terkecil dialami PT. Bank Jabar Banten pada akhir tahun 2003. Periode tahun 2006, meskipun dari satu bulan ke bulan berikutnya jumlah perolehan hasil pendapatan bunga bank relatif meningkat, namun diakhir tahun 2006 hasil pendapatan bunga yang berhasil diperoleh bank jumlahnya menurun $13,68 \%$. Jumlah tersebut merupakan jumlah perolehan pendapatan bunga terendah yang berhasil diraih selama delapan tahun terakhir. Penurunan pendapatan bunga tersebut disebabkan karena menurunnya tingkat suku bunga terutama untuk surat berharga, obligasi pemerintah, penempatan pada $\mathrm{BI}$ dan bank lain, serta wesel ekspor dan tagihan lainnya.

Tingkat suku bunga aktiva produktif yang turun dapat menghambat bank untuk memperoleh pendapatan yang lebih tinggi. Analisis hasil persamaan regresi bahwa naiknya 1 kali pendapatan bunga menyebabkan profitabilitas ikut naik lebih besar. Tinggi rendah pendapatan bunga yang berhasil diperoleh PT. Bank Jabar Banten tahun 2003 hingga tahun 2010 sangat dipengaruhi oleh jumlah dana yang disalurkan, tingkat suku bunga pinjaman yang berlaku saat itu, dan juga kolektibilitas pinjaman.

Agar kegiatan usaha bank berjalan, maka bank harus mempunyai sumber dana yang cukup yang selanjutnya akan digunakan oleh bank untuk menjalankan operasi bank diantaranya melalui pemberian kredit kepada masyarakat. Dengan manajemen yang baik, bank dapat memberikan jaminan keselamatan dana yang ada sekaligus memberikan peluang yang lebih besar bagi pihak perbankan untuk memperoleh laba sesuai yang diharapkan sebagai hasil dari pengelolaan dana tersebut.

Pada tahun 2007, perolehan pendapatan bunga meningkat $11,56 \%$ dibandingkan tahun sebelumnya dari Rp 1.132 .728 menjadi Rp 1.263.691. Tahun 2008, pendapatan bunga bank kembali mengalami peningkatan dari bulan pertama hingga akhir tahun sebesar $49,03 \%$ atau $\mathrm{Rp}$ 1.883.239. Tahun 2009 pendapatan bunga meningkat $24,63 \%$ menjadi $\mathrm{Rp}$ 2.347.040, sampai tahun 2010 pendapatan bunga meningkat $7,82 \%$ menjadi $R p$ 2.530.547.

Perkembangan asset dan laba PT. Bank Jabar Banten dari tahun 2003-2010 terus mengalami kenaikan. Namun berbeda dengan apa yang terjadi pada sisi Return On Assets (ROA), pada tabel terlihat perkembangan asset dan laba serta ROA cenderung stabil. Kenaikan dari asset belum dapat memaksimalkan ROA yang diperoleh PT. Bank Jabar Banten yang artinya kenaikan yang terjadi 
pada asset belum tentu berdampak pada kenaikan ROA. Misalnya pada periode tahun 2005-2006, 20082009 dan 2009-2010. Hasil analisis untuk profitabilitas PT. Bank Jabar Banten, tahun 2003-2010 berdasarkan ROA yang berhasil dicapai memiliki nilai yang cenderung stabil dan memiliki nilai rata-rata sebesar 2,94\% per tahun atau $1,96 \%$ per triwulan selama delapan tahun terakhir.

Berdasarkan data diatas dapat diketahui bahwa kenaikan asset belum mampu memaksimalkan laba yang diperoleh PT. Bank Jabar Banten. Kenaikan yang terjadi pada asset belum tentu berdampak pada naiknya Return On Assets (ROA). Dari penelitian ini gambaran profitabilitas yang diukur dengan Return On Assets (ROA) pada PT. Bank Jabar Banten mulai periode Maret 2003 sampai dengan Desember 2010 memiliki total ROA sebesar $62,73 \%$ dengan rata-rata 1,96\%. Nilai ini menunjukkan bahwa PT. Bank Jabar Banten berada diatas standar minimal yang ditetapkan Bank Indonesia untuk dapat dikatakan baik, dimana standar minimal adalah 1,5\%.

Berdasarkan hasil regresi linier sederhana yang telah diolah dalam penelitian ini, pengaruh pendapatan bunga $(X)$ terhadap profitabilitas $(\mathrm{Y})$ dapat diperoleh dari persamaan $\hat{Y}=0,91+1,10$ maka dari hasil perhitungan diperoleh nilai koefisien regresi antara pendapatan bunga dengan ROA sebesar 1,10 yang berarti setiap 1 kali kenaikan pendapatan bunga maka akan menaikkan ROA sebesar 1,10 kali. Koefisien regresi bertanda positif $(+)$ menunjukan bahwa pendapatan bunga mempunyai pengaruh positif terhadap profitabilitas bank (ROA). Pengaruh positif tersebut menujukkan bahwa jika pendapatan bunga mengalami kenaikan, maka ROA akan mengalami kenaikan. Dan sebaliknya, jika pendapatan bunga menurun, maka ROA akan mengalami penurunan. Tingginya pendapatan bunga yang diperoleh bank akan berpeluang meningkatkan perolehan laba dan secara tidak langsung akan ikut meningkatkan besarnya profitabilitas. Sebaliknya jika pendapatan kecil, maka laba bersih yang diperoleh bank pun akan berpeluang menjadi kecil atau menurun dan profitabilitas bank pun akan menurun.

Berdasarkan hasil pengujian hipotesis bahwa pendapatan bunga berpengaruh positif terhadap profitabilitas pada PT. Bank Jabar Banten, maka hipotesis yang penulis diajukan yaitu pengaruh pendapatan bunga terhadap profitabilitas pada PT. Bank Jabar Banten dapat diterima.

\section{Simpulan}

Berdasarkan hasil pengolahan data dan pembahasan, maka hasil penelitian dapat disimpulkan sebagai berikut:

1. Dari periode Maret tahun 2003 sampai dengan periode Desember 2010, pendapatan bunga yang diperoleh PT. Bank Jabar Banten setiap periodenya cenderung meningkat. Pendapatan bunga tertinggi diperoleh pada tahun 2010, sedangkan hasil perolehan pendapatan bunga terendah dialami PT. Bank Jabar Banten pada akhir tahun 2006.

2. Dari hasil penelitian yang telah dilakukan dapat diketahui Perkembangan profitabilitas yang diukur menggunakan Return on 
Assets (ROA) pada PT. Bank Jabar Banten selama tujuh tahun cenderung stabil, dapat dikatakan baik karena berada diatas batas minimal nilai ROA $1,5 \%$ menurut Surat Edaran BI tahun 2004.

3. Setelah dilakukan analisa regresi linier sederhana diperoleh persamaan pendapatan bunga terhadap profitabilitas adalah $Y=0,91$ + 1,10X. Berdasarkan persamaan tersebut maka dapat disimpulkan bahwa nilai koefisien regresi antara pendapatan bunga dengan ROA sebesar 1,10 yang berarti setiap kenaikan pendapatan bunga maka akan menaikan ROA sebesar 1,10 kali. Koefisien regresi bertanda positif $(+)$ tersebut menunjukkan bahwa pendapatan bunga mempunyai pengaruh terhadap profitabilitas bank, dimana setiap kenaikan pendapatan bunga akan mengakibatkan kenaikan pada profitabilitas (ROA).

\section{Daftar Pustaka}

Dahlan Siamat (2001). Manajemen Lembaga keuangan. Jakarta: Lembaga Penerbit Fakultas Ekonomi Universitas Indonesia.

Daniel, N. Lapoliwa. (2007) Akuntansi Perbankan. Jakarta: Institut Bankir Indonesia.

Eddie Rinaldy. (2008). Membaca Neraca Bank. Jakarta: Indonesia Legal Center Publishing.

Farah Margaretha. (2007). Manajemen Keuangan Bagi
Industri Jasa. Jakarta: Grasindo Gramedia Widiasarana Indonesia.

Hasibuan, Malayu. (2009). Dasardasar Perbankan. Jakarta: Bumi Aksara

lqbal Hasan. (2008). Analisis Data Penelitian Statistik. Jakarta: PT Bumi Askara.

Irham Fahmi. (2006). Analisis Investasi Dalam Prospektif Ekonomi dan Politik. Bandung: Refika Aditama.

Kasmir. (2008). Dasar- Dasar Perbankan. Jakarta: PT RajaGrafindo Persada. .(2008). Bank dan Lembaga Keuangan Lainnya. Jakarta: PT. RajaGrafindo Persada . (2008). Analisis Laporan Keuangan. Jakarta: PT RajaGrafindo Persada.

Lukman Dendawijaya. (2009). Manajemen Perbankan. Bogor: Ghalia Indonesia.

Moch Nazir. (2003). Metode Penelitian. Jakarta: Ghalia Indonesia.

M. Faisal Abdullah. (2004). Manajemen Perbankan (Teknik Analisis Kinerja Keuangan Bank), Ed. Revisi. Malang: UMM Press

Program Studi Pendidikan Akuntansi. (2010). Pedoman Operasional Penulisan Skripsi (POPS): Program Studi Pendidikan Akuntansi Universitas Pendidikan Indonesia.

S. Munawir. (2004). Analisa Laporan Keuangan. Yogyakarta: Liberty.

Selamet Riyadi. (2006). Banking Assets and Liability Management. Jakarta: 
Lembaga Penerbit Fakultas

Ekonomi Universitas Indonesia.

Simamora, Henry (2000). Akuntansi Basis Pengambilan Keputusan Bisnis. Jakarta: Salemba Empat.

Siswanto Sutojo. (2003). Manajemen Terapan Bank. Jakarta: Lembaga PPM dan Pustaka Binaman Presindo.
Sudjana. (2001). Metode Statistika. Bandung: Tarsito

Sugiyono. (2011). Metode Penelitian Kuantitatif Kualitatif dan $R \& D$. Bandung: CV. Alfabeta . (2011). Statistika Untuk Penelitian. Bandung: CV. Alfabeta.

Suharsimi Arikunto. (2006) Prosedur Penelitian Suatu Pendekatan Praktik. Jakarta: PT Rineka Cipta. 